\title{
Rapid and Quantitative Detection of Zoonotic Influenza A Virus Infection Utilizing Coumarin-derived dendrimer-based Fluorescent Immunochromatographic Strip Test (FICT)
}

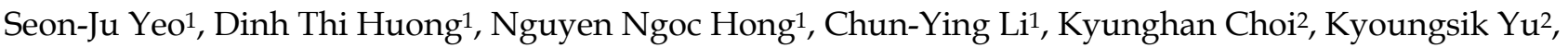 \\ Du-Young Choi ${ }^{3}$, Chom-Kyu Chong, ${ }^{4}$ Hak Soo Choi ${ }^{5}$, Shyam Kumar Mallik ${ }^{6}$, Hak Sung Kim ${ }^{6}$, Haan Woo \\ Sung 7 , Hyun Park ${ }^{\circledR}$ \\ 1. Zoonosis Research Center, Department of Infection Biology, School of Medicine, Wonkwang University, Iksan, Jeonbuk, Republic of \\ Korea. \\ 2. Department of Electrical Engineering, Korea Advanced Institute of Science and Technology, Daejeon, Chungnam, Republic of Korea \\ 3. Department of Pediatrics, School of Medicine, Wonkwang University, Iksan, Jeonbuk, Republic of Korea \\ 4. GenBody Inc, No.206, Biotech Business IC, DanKook University, San-29, Anseo-dong, Dongnam-gu, Cheonan, Chungnam, Republic of \\ Korea \\ 5. Division of Hematology/Oncology, Department of Medicine, Beth Israel Deaconess Medical Center, Harvard Medical School, Boston, \\ USA \\ 6. College of Pharmacy, Institute of Pharmaceutical Research and Development, Wonkwang University, Iksan, Jeonbuk, Republic of Korea \\ 7. College of Veterinary Medicine, Kangwon National University, Chunchon, Kangwon, Republic of Korea.
}

$\triangle$ Corresponding author: Hyun Park: Tel +82-63-850-6768, Fax +82-63-857-0342, Email: hyunpk@wku.ac.kr.

( ) Ivyspring International Publisher. This is an open-access article distributed under the terms of the Creative Commons License (http://creativecommons.org/ licenses/by-nc-nd/3.0/). Reproduction is permitted for personal, noncommercial use, provided that the article is in whole, unmodified, and properly cited.

Received: 2014.08.04; Accepted: 2014.09.08; Published: 2014.09.25

\begin{abstract}
Great efforts have been made to develop robust signal-generating fluorescence materials which will help in improving the rapid diagnostic test (RDT) in terms of sensitivity and quantification. In this study, we developed coumarin-derived dendrimer-based fluorescent immunochromatographic strip test (FICT) assay with enhanced sensitivity as a quantitative diagnostic tool in typical RDT environments. The accuracy of the proposed FICT was compared with that of dot blot immunoassay techniques and conventional RDTs. Through conjugation of coumarin-derived dendrimers with latex beads, fluorescent emission covering broad output spectral ranges was obtained which provided a distinct advantage of easy discrimination of the fluorescent emission of the latex beads with a simple insertion of a long-pass optical filter away from the excitation wavelength. The newly developed FICT assay was able to detect $100 \mathrm{ng} / \mathrm{I} 0 \mu \mathrm{L}$ of influenza A nucleoprotein (NP) antigen within 5 minutes, which corresponded to 2.5 -fold higher sensitivity than that of the dot blot immunoassay or conventional RDTs. Moreover, the FICT assay was confirmed to detect at least four avian influenza $A$ subtypes (H5N3, H7NI, H7N7, and H9N2). On applying the FICT to the clinical swab samples infected with respiratory viruses, our FICT assay was confirmed to differentiate influenza $\mathrm{HINI}$ infection from other respiratory viral diseases. These data demonstrate that the proposed FICT assay is able to detect zoonotic influenza A viruses with a high sensitivity, and it enables the quantitation of the infection intensity by providing the numerical diagnostic values; thus demonstrating enhanced detectability of influenza $A$ viruses.
\end{abstract}

Key words: Avian influenza A subtype, Fluorescent immunochromatographic strip test (FICT), Conjugation, Latex, Coumarin-derived dendrimer, Dot blot immunoassay. 


\section{Introduction}

Influenza viruses are categorized into three types, A, B, and C based on the antigenicity of the nucleoprotein (NP), and influenza $A$ viruses are causative agents of influenza, a contagious respiratory viral disease in a wide variety of animals such as humans, birds, and poultry [1-3]. H1N1, known as influenza virus or swine flu, was generated by combination of genes from human and pigs, and the outbreak occurred in Mexico, causing a devastating worldwide pandemic [4]. Human infections with influenza viruses derived directly from wild birds or poultry are rare, but, recently, over 600 human infections by influenza A (H5N1) viruses have been detected as fatal cases [5]. Upon contact with infected poultry, influenza A (H7) virus infections have also occurred in humans, causing general respiratory symptoms and one case of death [6-8]. However, in March 2013, human infections with a novel avian influenza A (H7N9) virus resulted in a number of deaths [9]. Avian H9N2 influenza A virus has caused repeated human infections in Asia [10]. Because influenza A viruses are responsible for the occasional global influenza pandemics in human populations due to the increased number of viruses crossing the animal-human host species barrier, it causes a significant impact on animal and human health, and hence, systematic surveillance is required [11]. Therefore, it is essential to timely screen for avian- and human influenza A viruses by monitoring at least three prominent subtypes of avian influenza A viruses (H5, H7, and $\mathrm{H9}$ ). As a result, rapidity in detecting the presence of influenza A virus during the acute phase of infection is crucial for providing immediate clinical treatment and sequestering procedures [12]. To detect influenza virus, viral culture, enzyme-linked immunosorbent assay (ELISA), fluorescence immunoassay, and polymerase chain reaction (PCR) techniques are mainly used in hospitals and laboratories [13]. However, these techniques require well-trained technicians and delicate lab equipments. Due to the test speed, portability, and ease of performance, immunoassay utilizing monoclonal antibody is commonly used in many hospital laboratories, emergency departments, and doctors' offices, and commercially available rapid influenza diagnostic tests (RIDTs) that detect the influenza virus NP antigen are widely used in clinical practice for diagnosing influenza [14, 15]. Despite its many advantages such as low cost, cell culture free, and easy field application, the use of the conventional RDT as a screening tool is limited because of variable sensitivities for detection of influenza A viruses [16-18]. It was confirmed that there were 29/1,346 (2.2\%) discordant test results between the automated reader and the visual interpretation of
RDTs [19]. As an alternative for identifying proteins derived from a target influenza virus, there is a strong demand for a highly sensitive diagnostic system that can detect and characterize influenza virus in nanoscale objects [20]. In recent years, for further improved sensitivity of influenza A detection, viral detection systems including magnetic bead-, nanoparticle-, and fluorescence-based assays have been introduced by several groups [12, 21-23]. However, they still present a challenge of integration of rapid screening method upon advancement of viral detection systems for field application. Among the above mentioned advanced viral detection systems, fluorescent materials act as powerful labels in developing innovative immunoassays for influenza A virus [24, 25]. Previously, coumarin-derived dendrimers, novel fluorescence materials excitable by light emitting diodes (LEDs), were confirmed as potential candidates for diagnosing malaria infection with higher performance of fluorescence-linked immunosorbent assay (FLISA) than ELISA [26]. Herein, we developed an innovative method that applies the coumarin-derived dendrimers to the influenza A RIDTs for quantification of diagnostic values through an LED-based portable strip reader; thus establishing a highly sensitive fluorescent immunochromatographic strip test (FICT). In this study, coumarin-derived dendrimers were integrated into the influenza A RIDTs for targeting the influenza A NP which is abundant in influenza A virus, and the fluorescence intensities were determined to detect the presence of avian and human influenza A viruses.

\section{Experimental}

\section{Materials and Reagents}

Aliphatic Amine Latex Beads (2\% w/v, $20 \mathrm{~nm})$ were purchased from Life technology and influenza A NP protein was purchased from Novus Biologicals. As two monoclonal antibodies (mAb) for the FICT, anti-influenza A -7307 and -7304 were purchased from Medix Biochemica. Aqueous glutaraldehyde $(8 \%$ in DW) solution and goat anti-mouse IgG were purchased from Sigma-Aldrich.

\section{Viruses}

Professor Du-young Choi (Wonkwang University, Korea) kindly provided H1N1- and other respiratory virus-infected patient samples. Professor Haan Woo Sung (Kangwon National University, Korea) kindly provided avian influenza viruses (H5N3, H7N1, H7N7, and H9N2)-infected samples (Table 1).

\section{Egg inoculation for virus culture and purification}

Hemagglutination assay (HA) was performed to 
assess the viral titer before virus amplification. Briefly, $50 \mu \mathrm{L}$ of PBS was added to a round-bottomed 96-well plate and an equivalent volume of diluted virus solution was added and after mixing it well; then, $50 \mu \mathrm{L}$ of the mixture was transferred to the next consecutive well. Equal volume of $0.5 \%$ red blood cells was added to the diluted virus solution, and cells were plated at room temperature (RT) before reading the agglutination test result. For determining the propagation of influenza viruses including avian influenza viruses (H5N3, H7N1, H7N7, and H9N2) and patient-collected swabs (H1N1), supernatant (50 $\mathrm{HAU} / 0.1 \mathrm{~mL}$ ) of the influenza virus was inoculated into the allantoic cavity of 9- to 11-day-old embryonated eggs. After 2 days, the allantoic fluid was collected and titrated by HA. Purification of influenza virus was performed as previously described [27]. Briefly, the allantoic fluid was subjected to centrifugation $(2600 \times \mathrm{g}$, Centrifuge 5804R, Eppendorf, Germany) at $4{ }^{\circ} \mathrm{C}$ for $5 \mathrm{~min}$. After centrifugation, the supernatant was layered over a $20 \%$ sucrose cushion in NTE buffer (100 mM NaCl, $10 \mathrm{mM}$ Tris- $\mathrm{HCl}$ (pH 7.4), $1 \mathrm{mM}$ EDTA), following concentration by ultracentrifugation $(112,600 \times \mathrm{g}, 2$ hours, a SW28 rotor (Beckman Coulter, Fullerton, California)). Precipitated protein was dissolved in PBS and subjected to HA titration for further Dot blot and FICT assays.

Table I. Characterization of four avian influenza virus subtypes.

\begin{tabular}{|c|c|c|c|}
\hline Name of avian influenza virus & $\begin{array}{l}\text { Sub- } \\
\text { type }\end{array}$ & $\begin{array}{l}\text { Location of } \\
\text { solation }\end{array}$ & $\begin{array}{l}\text { Host for } \\
\text { isolation }\end{array}$ \\
\hline $\begin{array}{l}\text { Ya-Lake ChungCho } \\
\text { 10-3-F1(2011) }\end{array}$ & H5N3 & $\begin{array}{l}\text { Lake of } \\
\text { ChungCho, } \\
\text { Sokcho, Korea }\end{array}$ & $\begin{array}{l}\text { Wild avian } \\
\text { mallard }\end{array}$ \\
\hline $\begin{array}{l}\text { Ya-Jeju, Youngsoori-12-2F4(2012) } \\
\text { A/common teal/Korea/KNU } \\
\text { YSR12/2012(H7N1) }\end{array}$ & H7N1 & Jeju, Korea & $\begin{array}{l}\text { Wide- } \\
\text { spread } \\
\text { common } \\
\text { teal }\end{array}$ \\
\hline $\begin{array}{l}\text { Ya-Lake Kyungpo } \\
\text {-12-2-F3(2011) } \\
\text { A/mallard/Korea/KNU } \\
\text { GPH12/2011(H7N7) }\end{array}$ & H7N7 & $\begin{array}{l}\text { Lake of } \\
\text { Kyungpo, } \\
\text { Kangrung, } \\
\text { Korea }\end{array}$ & $\begin{array}{l}\text { Wild avian } \\
\text { mallard }\end{array}$ \\
\hline $\begin{array}{l}\text { Jae-Songwoorijang-chicken-TR-TR } \\
\text { A/chicken/Korea/KNUSWR09/2009 } \\
\text { (H9N2) }\end{array}$ & H9N2 & $\begin{array}{l}\text { Pochun, } \\
\text { Korea }\end{array}$ & $\begin{array}{l}\text { Traditional } \\
\text { market } \\
\text { chicken }\end{array}$ \\
\hline
\end{tabular}

\section{Diagnostic strip and portable strip reader}

For the FICT, nitrocellulose membrane (EMD Millipore, Darmstadt, Germany) was used for antibody coating. The membrane was coated with $0.2 \mu \mathrm{g}$ of goat anti-mouse IgG (Life Technology) on the control line and $0.8 \mu \mathrm{g}$ of anti-influenza A NP on the test line respectively. After drying the membrane at $30{ }^{\circ} \mathrm{C}$ for two hours, the diagnostic strip was tested for FICT assay. A portable strip reader with a $450 \mathrm{~nm}$ LED, an optical filter with $590 \mathrm{~nm}$ wavelength, an optical spectrometer, and a stroller to load the diagnostic strip, was kindly provided by Dr. Chom-Kyu Chong (GenBody, Korea).

\section{Preparation of latex beads conjugated with coumarin-derived dendrimer and antibody}

Coumarin-derived dendrimer was provided by Professor Hak-Sung Kim (Wonkwang University, Korea) and characterized previously [28]. For covalent conjugation of $\mathrm{mAb}$ with latex and coumarin-derived dendrimer, $0.8 \mathrm{~mL}$ of aliphatic amine latex beads $(20$ $\mathrm{nm}$ ) were washed with PBS ( $\mathrm{pH} 7.4)$ and in the presence of $0.8 \mathrm{~mL}$ conjugation buffer $(0.1 \mathrm{M}$ sodium bicarbonate, $\mathrm{pH}$ 8.5), $128 \mu \mathrm{L}$ of coumarin-derived dendrimer $(1 \mathrm{mg} / \mathrm{mL}$ in DMSO) was added to latex in the conjugation buffer at RT for 1 hour with shaking. After washing the latex beads twice with PBS, coumarin-derived dendrimer-conjugated latex beads were resuspended with $0.8 \mathrm{ml}$ of anti-influenza A NP (1 $\mathrm{mg} / \mathrm{mL}$ ) and incubated at $4{ }^{\circ} \mathrm{C}$. After one hour, glutaraldehyde $(0.5 \mathrm{~mL})$ was slowly added to the mixture of latex and antibody and it was vortexed well for 1 minute. After vortexing, the conjugate mixture was incubated at $4{ }^{\circ} \mathrm{C}$ for 2 hours with shaking and then washed with PBS twice. The precipitated bioconjugates were resuspended in $1 \mathrm{~mL}$ of $0.1 \%$ bovine serum albumin (BSA) (Sigma), making $0.8 \mathrm{mg} / \mathrm{mL}$ of $\mathrm{mAb}$ on the latex surface and it was stored at $4{ }^{\circ} \mathrm{C}$.

\section{Dot blot immunoassay}

The polyvinylidene fluoride (PVDF) membrane (Millipore) was spotted with $10 \mu \mathrm{L}$ of diluted virus-infected samples on the surface and dried at $37^{\circ} \mathrm{C}$ for 90 minutes. After complete drying, the membrane was blocked with 5\% non-fat dried milk in PBST (PBS, $0.1 \%$ Tween 20) for 1 hour. The blocked membrane was incubated with a primary antibody $(1 \mu \mathrm{g} / \mathrm{mL})$ in $5 \%$ BSA for 16 hours at $4{ }^{\circ} \mathrm{C}$. After washing the membrane with PBST three times, horseradish peroxidase (HRP)-conjugated anti-mouse IgG (Life technology) was applied to the membrane and the membrane was incubated at RT for 1 hour at a mild shaking speed. Finally, the membrane was washed with PBST three times and chemiluminescence was detected within 1 minute by applying ECL substrate (Bio-Rad) to the membrane.

\section{FICT and RDT}

After application of $10 \mu \mathrm{L}$ of the bioconjugate to the conjugate pad in the diagnostic strip, $10 \mu \mathrm{L}$ swab samples or diluted viral antigens were applied to the diagnostic strip and $100 \mu \mathrm{L}$ sample diluent buffer ( 25 mM HEPES ( $\mathrm{pH} 7.5$ ), $100 \mathrm{mM} \mathrm{NaCl}, 2.5 \mathrm{mM} \mathrm{MgCl}{ }_{2}$, $0.1 \%$ NP40) was added to the samples. The diagnostic strip was kept in a dark place for 5 minutes, and the 
fluorescent intensity was measured quantitatively by the portable strip reader. To compare the performance of FICT with that of RDT, a commercialized RDT (Humasis, Korea) was used in this study. Equal amount of swab samples and viral solutions were used for the RDT in the presence of sample buffer, and it was read with the naked eye within 15 minutes.

\section{Measurement of the spectroscopic properties of coumarin-derived dendrimer latex bioconjugate}

An ultraviolet/visible spectrometer (Optizen Pop, Mecasys, Korea) and a spectral scanning multimode reader (Varioskan Flash, Thermo Electron Corporation, USA) were used to measure the absorption and emission spectra, respectively. During each measurement, the sample solution was illuminated by the excitation light, and the absorption/emission spectra were subsequently measured by the spectrometer at RT. The integration time varied according to the sample concentration. A deuterium/tungsten lamp was used for absorption measurements. The emission spectra were obtained with a filtered Xenon flash lamp whose peak wavelength was $450 \mathrm{~nm}$.

\section{Ethical considerations}

The study was approved by the Institutional Review Board of the Wonkwang University Hospital (Approval No. 1263).

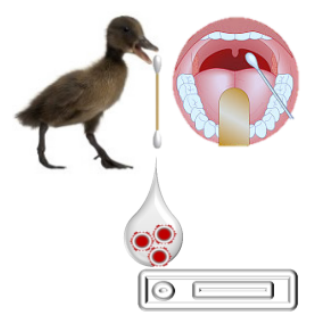

diagnostic strip

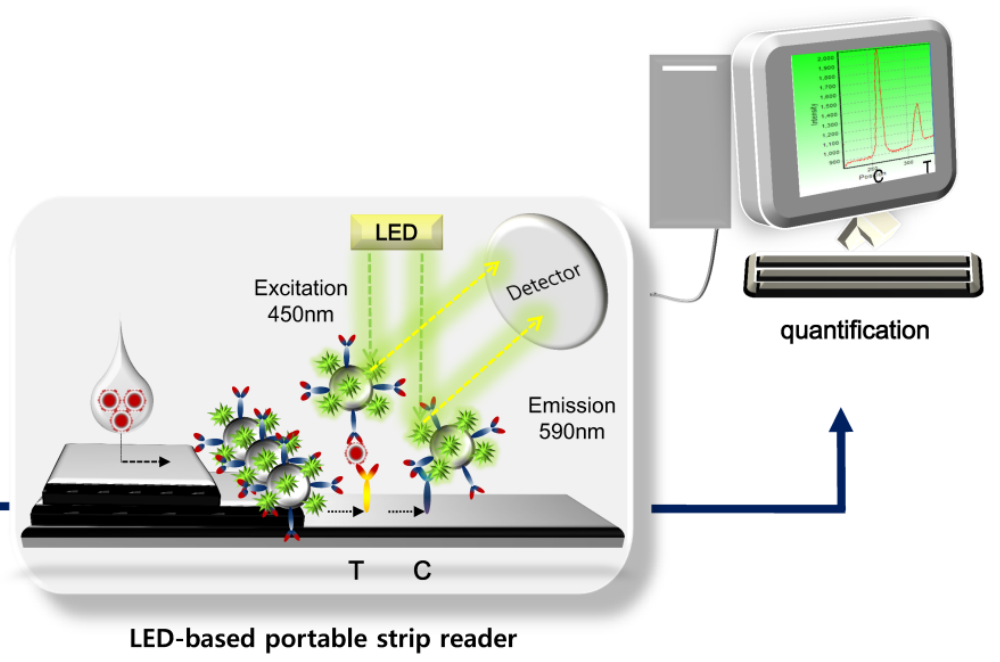

\begin{tabular}{|c|c|c|c|}
\hline 类急 & Coumarin-derived dendrimer & & Anti-mouse IgG \\
\hline & Aliphatic amine latex bead (20 nm) & $y$ & Anti-Influenza NP-1 \\
\hline & \multirow{2}{*}{$\begin{array}{l}\text { Conjugate: Latex conjugated with } \mathrm{mAb} \text { and } \\
\text { Coumarin-derived dendrimer }\end{array}$} & $Y$ & Anti-Influenza NP-2 \\
\hline & & (0) & Influenza A viruses \\
\hline
\end{tabular}

Figure I. Schematic illustration of the FICT assay using RDT strip and portable strip reader. After application of clinical samples to RDT, a LED-based portable strip reader and a personal computer quantify the diagnostic values.

\section{Results and Discussion}

\section{Working principle of the FICT diagnostic assay}

Figure 1 illustrates the scheme of quantitative FICT assay, using immunochromatographic strip test (ICT). The ICT is the simplest and commercial rapid diagnostic tool [29]. As a point-of-care diagnostic tool, it is important that it plays a role in generating and transducing the signal in an immunoassay, which determines the performance of ICT for quantification in addition to high sensitivity [30]. Recently, to develop signals in the ICT, many advanced candidates such as latex particles and organic fluorophores have been explored to adapt to the rapid diagnostic test strip [31-33]. The test strip for ICT consists of a conjugate pad, sample pad, nitrocellulose membrane, and absorbent pad. In this study, a quantitative rapid diagnostic strip was fabricated using coumarin-derived dendrimer-mediated fluorescence material and latex. Anti-influenza A nucleoprotein (NP) and anti-mouse IgG were coated onto the nitrocellulose membrane and the surface-conjugated latex with another $\mathrm{mAb}$ of influenza A NP and coumarin-derived dendrimers were pre-loaded on the conjugation pad, completing a diagnostic strip. Test zone (T) indicated the place where anti-influenza A NP is coated, and in the absence of target NP antigens, latex conjugates could not react with $\mathrm{mAb}$ in the $\mathrm{T}$ zone. Whereas in the presence of influenza A NP antigens, the lateral flow of the conjugate (latex conjugated with anti-influenza A NP and coumarin-derived dendrimers) along the membrane was supposed to be paused in the $\mathrm{T}$ zone due to immunoreactivity among coating $\mathrm{mAb}$, antigen, and conjugated $\mathrm{mAb}$. Finally, the fluorescence intensity of coumarin-derived dendrimers was detected by the LED-based portable strip reader. In the control zone (C), anti-mouse IgG recognized the anti-influenza NP on the surface of latex, providing the level of lateral flow during each test. It has been reported that the fluorescence intensity ratio between the 
test zone (T) and the control zone (C) was used to determine the amount of analyte in the sample [30], and therefore, each $\mathrm{T}$ peak value was divided by each $C$ peak value to quantify the relative diagnostic value in this study. As analytes, four avian influenza A virus subtypes derived from isolates of wild birds (mallard, common teal, and chicken) and human swab samples were loaded onto the sample pad with sample lysis buffer. After application, the fluorescence intensity was read within 5 minutes in a dark place by the LED-based portable strip reader. The excitation and detection wavelengths were $450 \mathrm{~nm}$ and $590 \mathrm{~nm}$, respectively.

\section{Characterization of conjugation}

$\mathrm{N}$-hydroxysuccinimide (NHS) esters of coumarin-derived dendrimers reacted with primary amine groups $\left(-\mathrm{NH}_{2}\right)$ on the latex surface in sodium biocarbonate buffer ( $\mathrm{pH} 8.5)$ to form stable amide bonds upon release of NHS (Figure 2 (a) and (b)). Through carboxylates $(-\mathrm{COOH})$ of hydrophilic glutaraldehyde, amines (-NH2) on the antibody were conjugated by forming the amide bond (Figure 2 (c) and (d)). After conjugation, the conjugated $\mathrm{mAb}$ on latex was purified by high speed centrifugation and washing.

\section{Characteristics of the conjugate}

Fluorescence and immunogenicity of mAb conjugated with latex and coumarin-derived dendrimer were characterized by dot-blot immunoassay. Fluorescence intensity was observed under UV-visible light or fluorescence with $460 \mathrm{~nm}$ excitation and 560 $\mathrm{nm}$ emission was measured by using an Infinite F200 microplate reader (TECAN, Männedorf, Switzerland). After completing the conjugation, $0.8 \mathrm{mg} / \mathrm{mL} \mathrm{mAb}$ was anticipated to be conjugated with latex according to the mathematical calculation, provided all antibodies reacted with latex to yield covalent conjugates. When $4 \mu \mathrm{g} / 10 \mathrm{uL}$ of conjugated mAb, $1 / 2$ concentration of the FICT application, was dotted on the PVDF, yellow color of the conjugated $\mathrm{mAb}$ was observed by the naked eye and under UV visible light. To put it simply, the fluorescence intensity was detectable at the spot of conjugated $\mathrm{mAb}$, confirming the fluorescence signaling of latex conjugated with $\mathrm{mAb}$ and coumarin (Figure 3(a)).

(a)

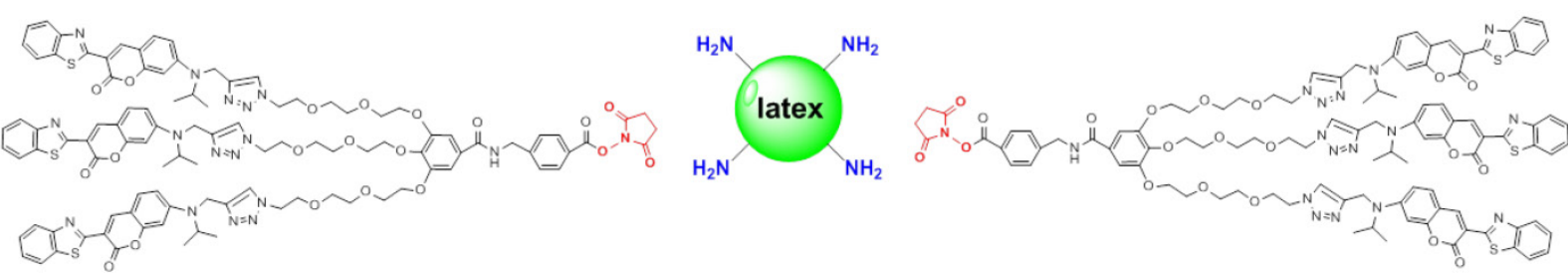

(b)
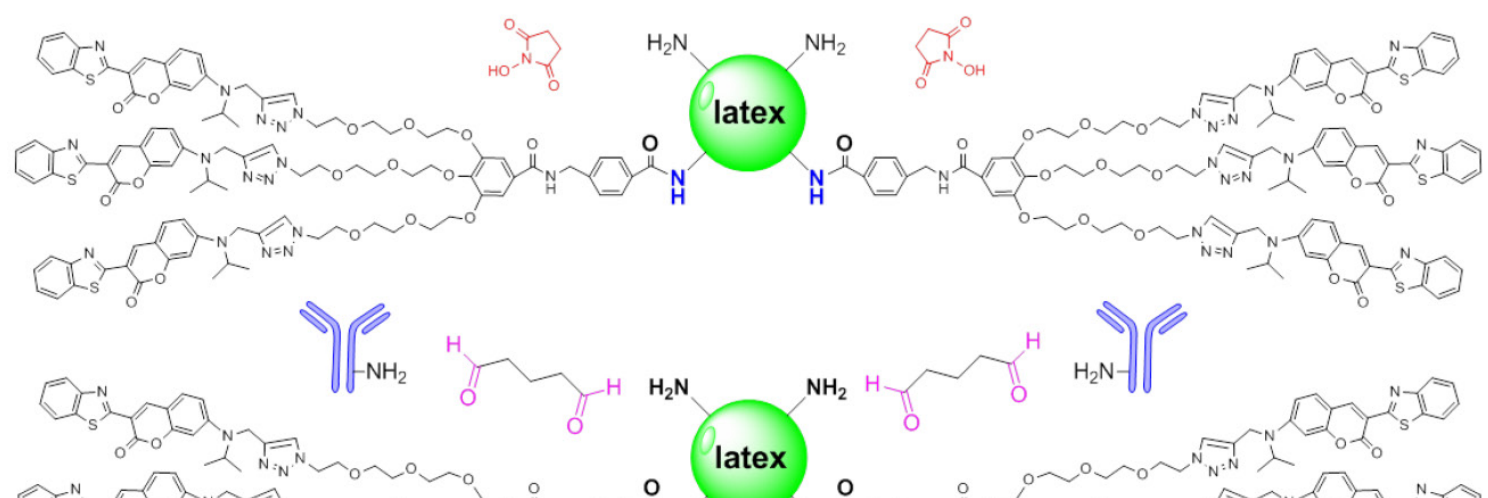

(c)

latex

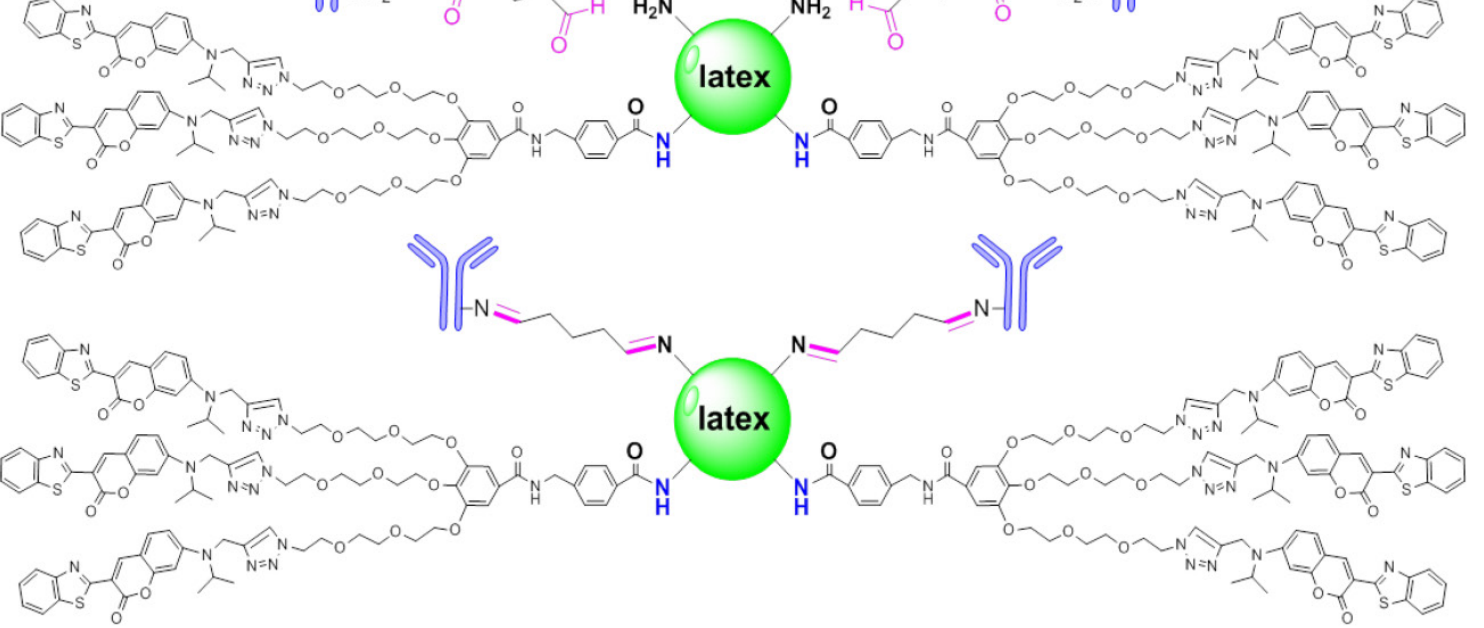

(d)

Figure 2. Schematic diagram of conjugation. Latex was conjugated with glutaraldehyde and antibody by forming amide bonds in biocarbonate buffer ( $\mathrm{pH}$ 8.5) (a-d). 
(a)

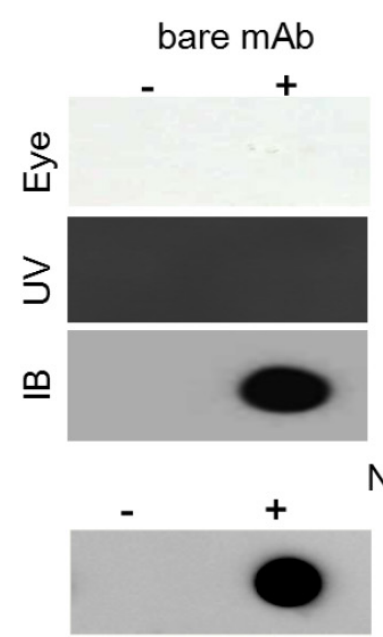

IB:

bare $\mathrm{mAb}$
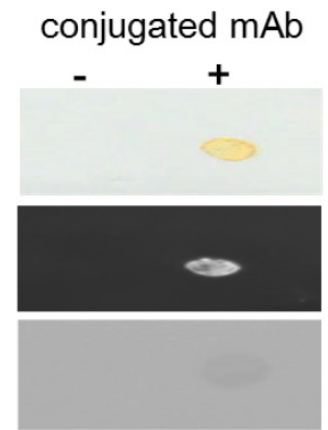

NP

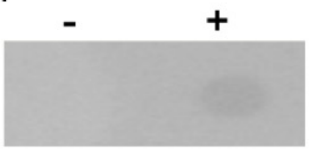

conjugated $\mathrm{mAb}$

(c)

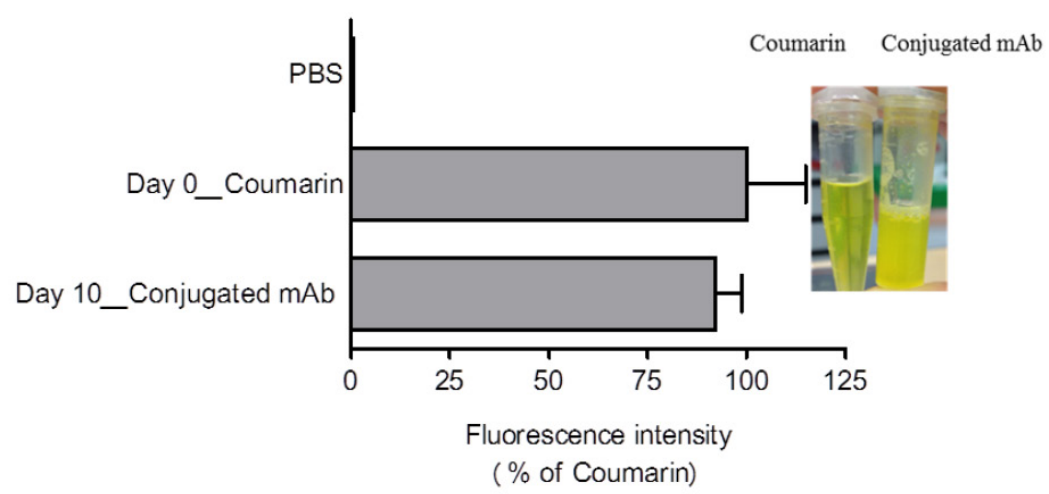

(d)
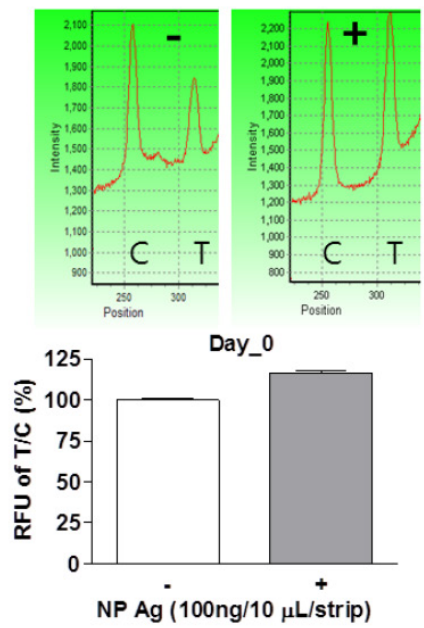

(e)
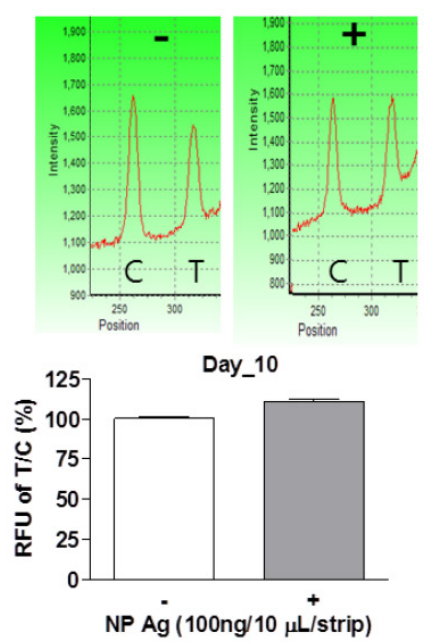

Figure 3. Characterization of $\mathrm{mAb}$ and coumarin-derived dendrimer in the conjugate. After conjugation, fluorescence level of the conjugate was observed with the naked eye and UV. The presence of antibody on the surface of latex was investigated with immunoblot (a). The immunoreactivity of mAb after conjugation was confirmed by dot-blot immunoassay (b). At day 10, the level of fluorescence emission on latex was compared to that in the original coumarin-derived dendrimers solution with equal concentration (c) and stability of conjugate was determined by FICT at 10 days ( $\mathrm{d}$ and e). Coumarin: coumarin-derived dendrimer, Conjugated Ab: Latex conjugated with mAb and coumarin-derived dendrimer, NP: Nucleoprotein.

The efficiency of Ab conjugation with latex was assessed by comparing with bare or conjugated $\mathrm{mAb}$ in dot-blot immunoassay. The conjugated $\mathrm{mAb}$ and unconjugated $\mathrm{mAb}$ were applied to the PVDF and the chemiluminescence levels were detected by using HRP anti-mouse IgG. After screening the amount of conjugated $\mathrm{mAb}$ on latex by immunoassay, in spite of the high fluorescence intensity of conjugated $A b$, the chemiluminescence signal with conjugated $\mathrm{mAb}$ was significantly low compared to that with bare $\mathrm{mAb}$ (Figure $3(\mathrm{~b})$ ). The reason for low chemiluminescence signaling could be low reactivity of the secondary antibody with the conjugated $\mathrm{mAb}$ due to steric hindrance of latex or conjugation of few mAbs with latex due to low efficiency of covalent binding [30]. The immunoreactive property of conjugated $\mathrm{mAb}$ was confirmed by using influenza A NP protein and the antigen was still detectable by using the conjugated $\mathrm{mAb}$. After storing the conjugate at $4{ }^{\circ} \mathrm{C}$ for 10 days, fluorescence intensity of the conjugate was compared with that of an equal amount of fresh coumarin-derived dendrimers. At 10 days, the conjugated $\mathrm{mAb}$ was still showing a high fluorescence intensity of $92.19 \pm 5.34$ (mean \pm SD) \% in comparison to the fresh latex-free coumarin-derived dendrimer ((Figure 3 (c)). We performed a FICT assay with 10-day-old conjugated $\mathrm{mAb}$ and compared it with that of fresh conjugate (day 0 ). The FICT showed a positive value at 10-day-old conjugate (Figure 3 (d) and (e)). The characteristics of the conjugated $\mathrm{mAb}$ implicate that highly sensitive and stable fluorescence intensity of coumarin-derived dendrimer plays an essential role in the discernible diagnostic performance of the conjugated complex. 
(a)

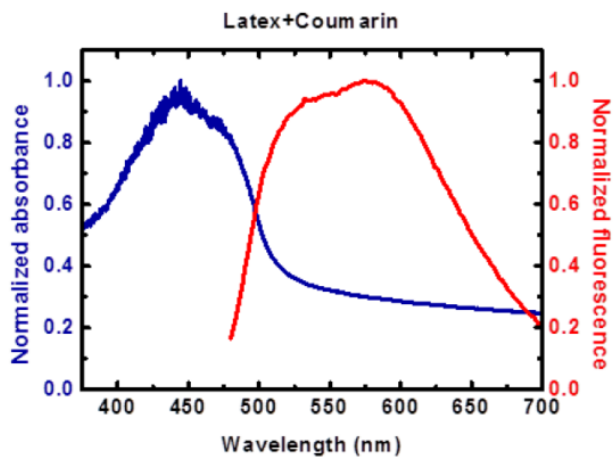

(b)

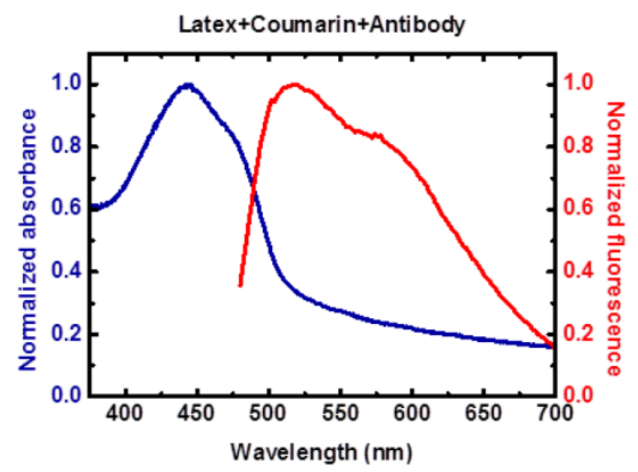

(c)

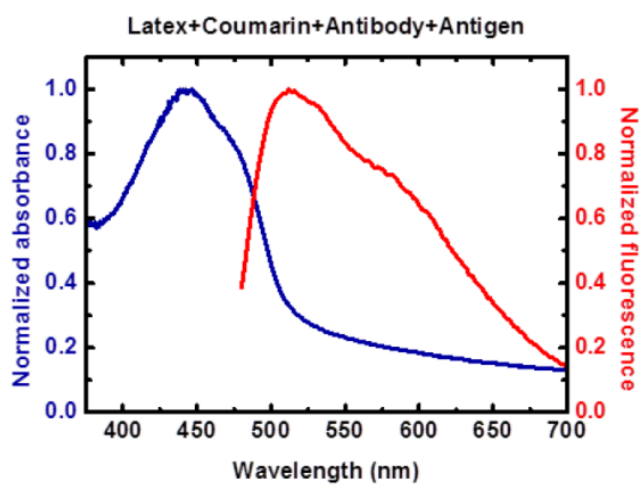

Figure 4. Spectral properties of the conjugate. Fluorescence absorption and emission spectra were measured and compared under various conjugation scenarios in distilled water by I:I dilution. The broad wavelength range of fluorescent emission spectra from the latex bead conjugate was observed (a). The fluorescence emission intensity was influenced by additional mAb conjugation at 550-600 nm (b). In the presence of the NP antigen, the fluorescence emission at longer wavelengths was not significantly changed (c).

\section{Optical properties (fluorescence absorption and emission spectra) of the conjugate and antigen}

The optical properties (fluorescence absorption and emission spectra) of the latex beads conjugated with coumarin-derived dendrimer, $\mathrm{mAb}$, and influenza A NP antigen were examined. The latex beads conjugated with coumarin-derived dendrimer only (Figure 4A) had a relatively wide absorption wavelength range with the main peak near $450 \mathrm{~nm}$. The addition of $\mathrm{mAb}$ (Figure 4 (b)) and antigen (Figure 4 (c)) did not significantly alter the absorption spectra, and the main absorption peak remained near $450 \mathrm{~nm}$. Such stable and broad absorption characteristics allow the use of broadband light sources, such as light emitting diodes, for facile fluorescent excitation. The absorption tails at longer wavelengths were mainly from the latex bead. The fluorescent emission spectra also exhibited wide spectral ranges, and therefore, the presence of fluorescent latex beads could be easily detected with the emission optical filter $(590 \mathrm{~nm}$ wavelength) as employed in the LED-based portable strip reader. This result was also consistent with the previous report of coumarin-derived dendrimer characterization [28].

\section{Comparison of the lowest detectable concentration}

For the field application of the point-of-care diagnostic tool, it should be easily operated by lay people. FICT assay was simply performed by adding 10 $\mu \mathrm{L}$ of the sample with additional sample dilution buffer on the sample pad. The diagnostic values were quickly measured by the LED-based portable strip reader. On the basis of the preliminary data, the optimal reactive time ranged from 5 to 10 minutes, and the reactive time was determined to be 5 minutes in this study. The detection sensitivity of the FICT assay was determined by analyzing standard influenza A $\mathrm{NP}$ antigens at a concentration from $10 \mathrm{ng} / 10 \mu \mathrm{L}$ to $500 \mathrm{ng} / 10 \mu \mathrm{L}$. For interpretation of the reactivity in the $\mathrm{T}$ zone, each $\mathrm{T}$ peak value was normalized by each $C$ zone because sample migration could vary according to the lateral flow. Therefore, the peak value of each control zone implies the migration of conjugated $\mathrm{mAb}$ along the membrane of ICTs. Figure 5 (a) and 5 (b) show that the $\mathrm{T} / \mathrm{C}$ ratio derived from each peak of fluorescence was enhanced by a gradual increase in influenza A NP antigens, and the detectable minimum concentration of NP antigen was $100 \mathrm{ng} / 10 \mu \mathrm{L}$, which was the lowest detectable concentration (LDC) of FICT. Despite the nonspecific peak in the T zone in FICT, the cut-off values indicated the positive and negative values. In contrast, the LDC of both the dot-blot immunoassay and RDT was $250 \mathrm{ng} / 10 \mu \mathrm{L}$, indicating that those methods were 2.5 -fold less sensitive than the FICT assay (Figure 5 (c)).

\section{Detection of avian influenza virus subtypes}

Because the conjugated $\mathrm{mAb}$ targeted the influenza A NP protein, FICT was also used to detect avian influenza A viral particles isolated from wild birds. To assess the potential of FICT for screening various avian influenza A subtypes transmissible between humans and birds, four sequence-confirmed avian influenza A subtypes (H5N3, H7N1, H7N7, and H9N2) were amplified in fertilized eggs and then pu- 
rified for further study. Using $40 \mathrm{HAU} / 10 \mu \mathrm{L}$ of viral antigens, fluorescence intensities of four avian subtypes (H5N3, H7N1, H7N7, and H9N2) were compared to that of H1N1, and they were found to be lower than the fluorescence intensity of H1N1 (Figure 6 (a) and 6 (b)). Among the 4 subtypes, H7N1 and H7N7 showed the highest fluorescence intensity in both FICT and dot-blot immunoassay, demonstrating a highly correlated performance of these two different

(a)
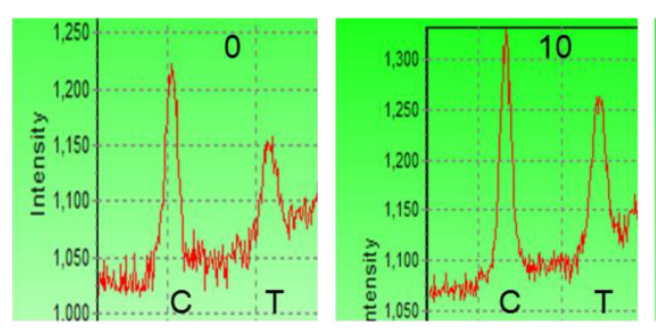

(b)

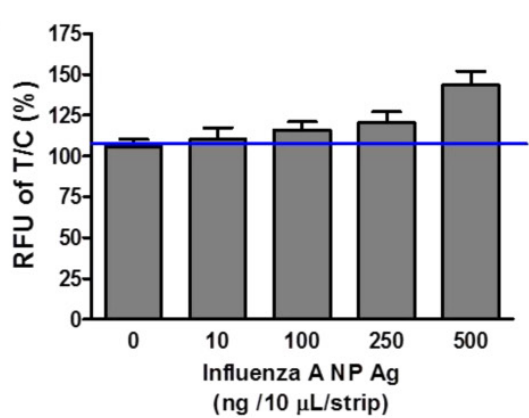

(c) assays. In Figure 6 (c), the immunoreactivity of mAb-NP against H1N1 as well as against four avian subtypes was confirmed by dot-blot immunoassay and T/C values of FICT against avian influenza viruses were highly correlated with those of dot-blot immunoassay. Therefore, FICT based on the coumarin-derived dendrimer is a reliable, accurate, and rapid diagnostic tool for the detection of human and avian influenza A viruses.
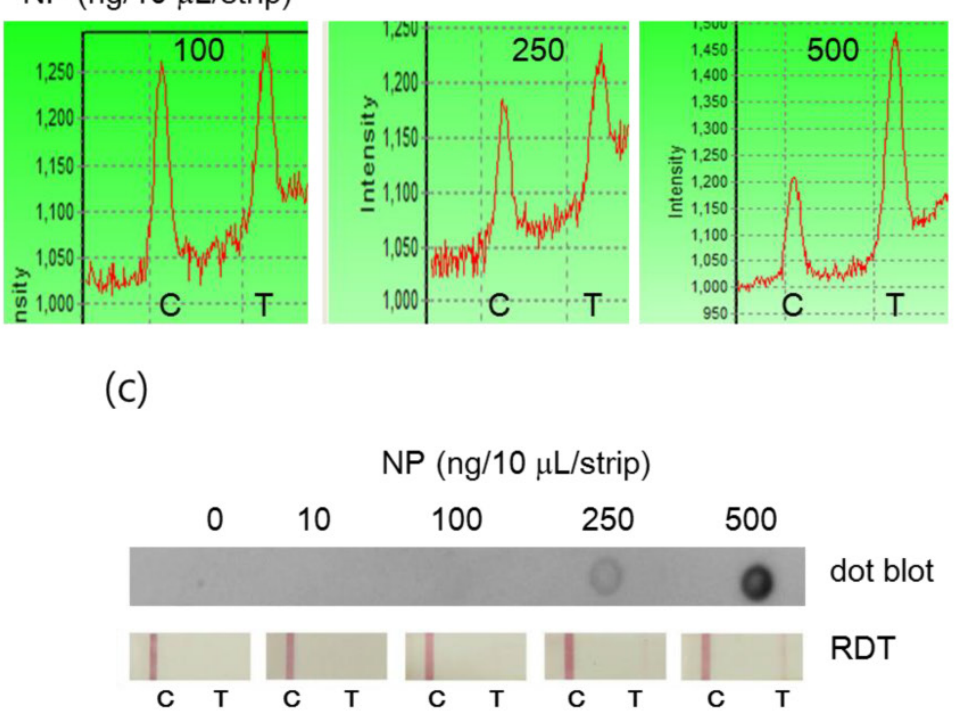

Figure 5. Comparison of the lowest detectable concentration (LDC) among the FICT assay, Dot blot, and RDT. Influenza virus A nucleoprotein (NP) was serially diluted in PBS and applied to the FICT assay. T/C ratio (\%) indicated I00 ng/strip as the LDC of the FICT assay (a and b) and 250 (ng/strip/I0 $\mu \mathrm{L}$ ) as the LDC of both the dot blot and RDT (c).

(a)
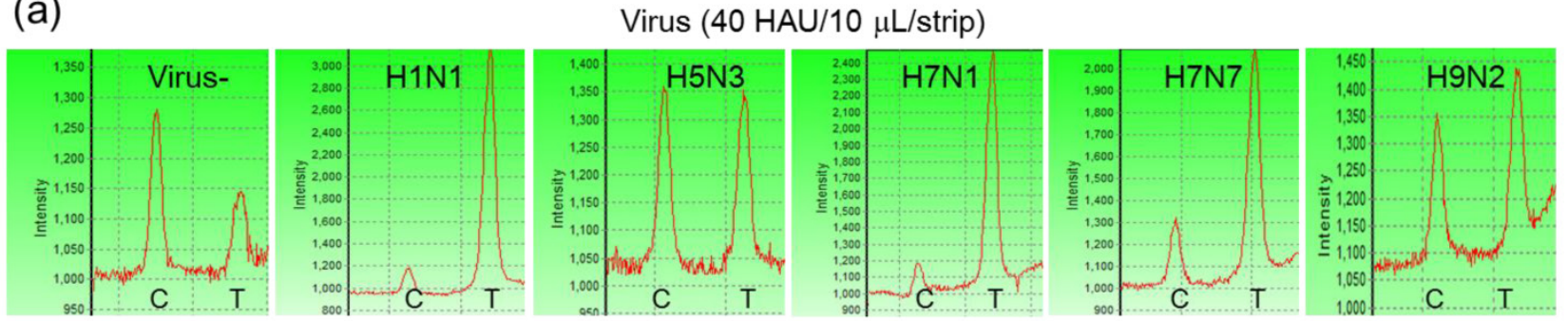

(b)

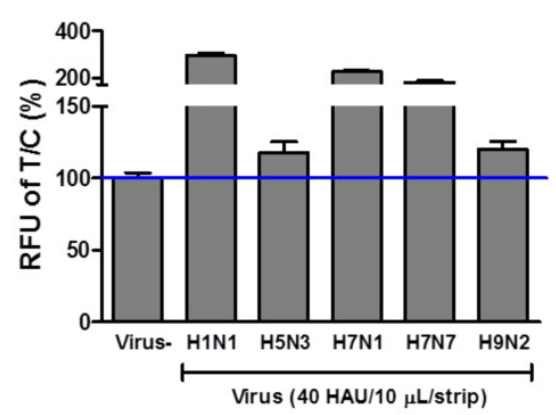

(c)

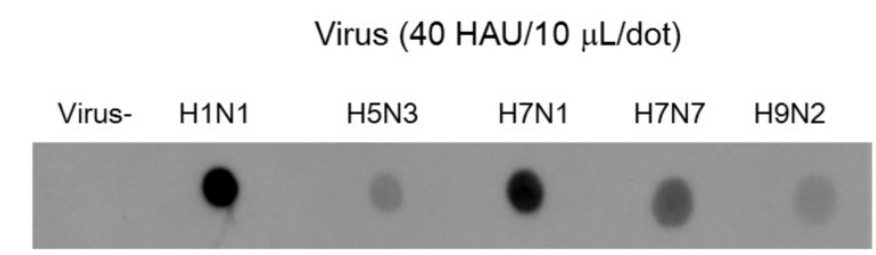

IB: bare mAb

Figure 6. FICT assay for detection of avian influenza virus subtypes. Four avian influenza virus subtypes isolated from several different locations in Korea were tested with the FICT assay. The amount of virus was titrated by the HA assay and applied to the FICT assay with 40 HAU/strip (a). T/C ratio (\%) indicated that all four subtypes were found to be positive with FICT (b) and they were compared with Dot-blot analysis (c). 


\section{Clinical evaluation of the FICT assay}

Furthermore, in order to evaluate the potential of FICT to detect the influenza virus quantitatively, clinical patient samples were assessed by applying FICT. Through the FICT assay, diagnostic values were digitized, allowing the user to quantify the diagnostic intensity objectively. The presence of each virus in patient samples was confirmed by cell culture and PCR. Moreover, the specificity of FICT was confirmed with $10 \mu \mathrm{L}$ solution obtained from neutralizing buffered swab samples (two normal samples, five H1N1-infected patient samples, and four different respiratory virus-infected patient samples). Test zone (T) showed higher peak values than the control zone (C) peak when H1N1 patients samples were applied to FICT, but each peak value of the T zone was lower than the peak value of the $C$ zone in negative samples as well as in other respiratory virus-infected samples (Figure 7 (a)). Each relative value of $\mathrm{T} / \mathrm{C}$ ratio showed the cut-off line between influenza A virus (H1N1)-infected samples and negative samples (normal and other respiratory viruses) (Figure 7 (b)). The quantitative analysis of clinical samples with FICT was conducted by preparing a calibration curve of HAU titers. The fluorescent values of clinical sam-

(a)

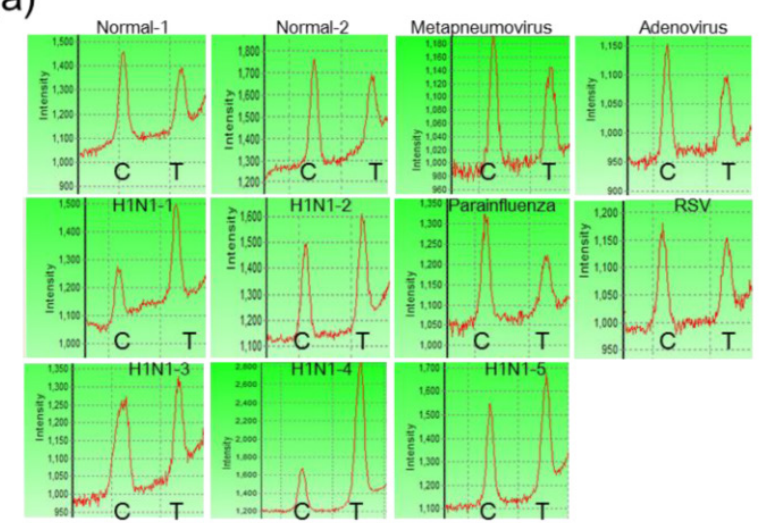

(b)

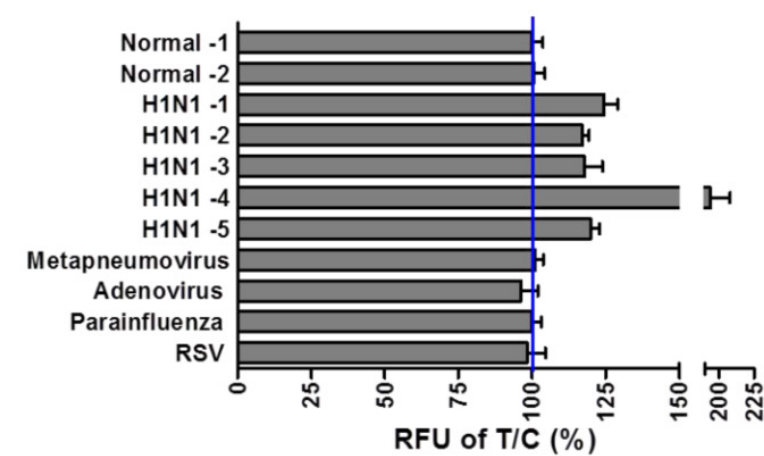

ples were incorporated into the standard curve which was created with the T/C value (\%) of serially diluted H1N1 HAU titer and a linear regression $\left(R^{2}=0.945\right)$ was used to calculate HAU titers (Figure 7 (c) and (d)). In this study, the FICT assay showed a linear range of 0.625-40 HAU $/ 10 \mu \mathrm{L}$ for the purified avian influenza virus. To compare the range of quantification between FICT and RDT, we investigated the quantitative range of RDT. As shown in Figure 7 (e), the quantitative range of RDT was 5-40 HAU/10 $\mu \mathrm{L}$. Using a fluorescent-linked immunosorbent assay (FLISA), a linear range of quantum-dot-based fluoroimmunoassay has been reported as $8-510 \mathrm{ng} / \mathrm{mL}$ for the purified H5N1 virus with polyclonal antibody against H5N1 [34]. This method is another experimental work using fluorescence probe but due to different experimental condition, it is not convenient to compare the performance between the quantum-dot-based FLISA and coumarin-derived dendrimer-based FICT. The results showed that the sensitivity of quantum-dot-based FLISA was 30-fold greater than the conventional ELISA and the sensitivity of coumarin-derived dendrimer-based FICT was 2.5-fold higher than the colloidal gold-based RDT.

(c)

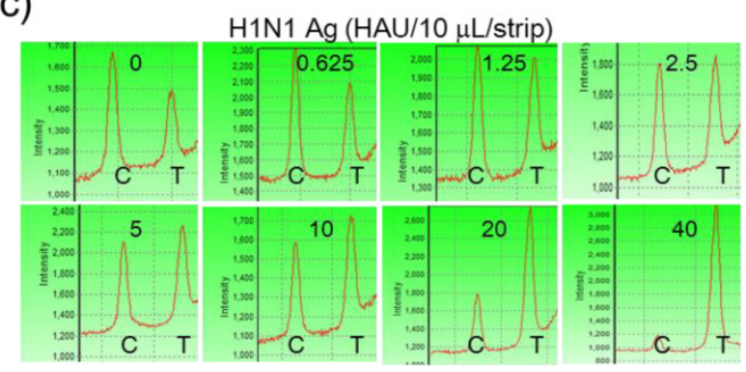

(d)

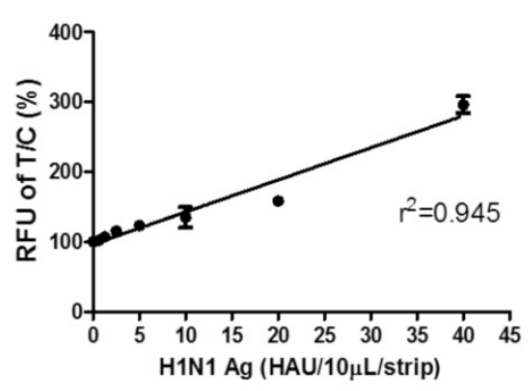

(e)

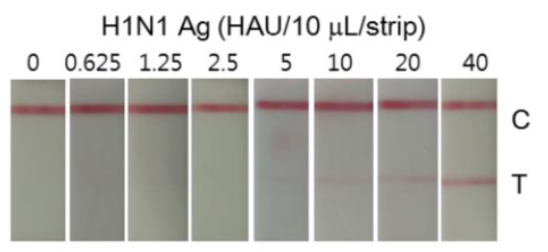

Figure 7. Clinical evaluation of the FICT assay. HINI-positive patient samples $(n=5)$ and other respiratory viruses (Metapneumovirus, Adenovirus, Parainfluenza, and Respiratory syncytial virus (RSV))-infected swab samples $(n=4)$ and two normal swab samples $(n=2)$ were applied to the FICT assay $(a)$. T/C value (\%) in all HINI patients were above the cut-off line (blue line) (b). Differently diluted HINI virus antigens were tested with the FICT assay to provide the calibration curve of the FICT assay (c). Quantitative value in $\mathrm{HINI}$ patients diagnosed as positive by the FICT assay was incorporated in the calibration curve of $\mathrm{HINI}$ antigen and used for analyzing the $\mathrm{HAU}$ titer of clinical samples (d). The quantitative range of RDT was determined with the serially diluted HINI virus antigen. 
Table 2. Comparison of performance of FICT to that of RDT using clinical samples.

\begin{tabular}{|c|c|c|c|c|c|c|c|c|c|}
\hline \multirow[b]{2}{*}{ ID } & \multicolumn{2}{|c|}{ Culture } & \multicolumn{2}{|c|}{ PCR } & \multicolumn{3}{|c|}{ RDT } & \multicolumn{2}{|c|}{ FICT } \\
\hline & $\begin{array}{c}\text { Pathogen } \\
\text { specific }\end{array}$ & $\begin{array}{c}\text { Influenza } \\
\text { A }\end{array}$ & $\begin{array}{c}\text { Pathogen } \\
\text { specific }\end{array}$ & $\begin{array}{c}\text { Influenza } \\
\text { A }\end{array}$ & C & $\mathrm{T}$ & & $\begin{array}{l}\text { Converted H } \\
(\text { mean } \pm \mathrm{SD})\end{array}$ & $10 \mu \mathrm{L}$ \\
\hline Normal-1 & - & - & - & - & & & - & - & - \\
\hline Normal-2 & - & - & - & - & & & - & - & - \\
\hline $\mathrm{H} 1 \mathrm{~N} 1-1$ & - & + & - & + & & & - & $6.07 \pm 0.99$ & + \\
\hline $\mathrm{H} 1 \mathrm{~N} 1-2$ & - & + & - & + & & & - & $4.5 \pm 0.49$ & + \\
\hline H1N1-3 & - & + & - & + & & & $-/+$ & $4.6 \pm 1.31$ & + \\
\hline $\mathrm{H} 1 \mathrm{~N} 1-4$ & - & + & - & + & & & + & $21.2 \pm 3.03$ & + \\
\hline H1N1-5 & - & + & - & + & & & + & $5.1 \pm 0.65$ & + \\
\hline $\begin{array}{c}\text { Metapneumovirus } \\
\text { positive }\end{array}$ & + & - & + & - & & & - & - & - \\
\hline Adenovirus positive & + & - & + & - & & & - & - & - \\
\hline Parainfluenza positive & + & - & + & - & & & - & - & - \\
\hline RSV positive & + & - & + & - & & & - & - & - \\
\hline
\end{tabular}

The HAU titer in five H1N1-positive patients was quantitatively determined as $6.09 \pm 0.99,4.5 \pm 0.49$ $4.6 \pm 1.3,21.2 \pm 3.03$, and $5.1 \pm 0.65$ (mean \pm SD) $\mathrm{HAU} / 10 \mathrm{uL}$, respectively and their titers were confirmed by HA assay.

Additionally, the diagnostic accuracy of FICT was evaluated by comparing with that of conventional RDT as described previously [35] (Table 2). The FICT performance was highly correlated with culture and PCR results; but when the same clinical samples were applied to RDT, two negative results were obtained among the five H1N1-positive patients in $10 \mu \mathrm{L}$ of a sample scale. In contrast, with the FICT assay, all of the PCR/culture positive H1N1 patients were found to be positive. Among the three positive samples in the RDT, a case of influenza A (H1N1-3) was rarely diagnosed due to the weak colorimetric result; but in the FICT assay, the T/C value (\%) was higher than the cut-off value. Therefore, FICT was not only an accurate but also a quantitative assay for detection of influenza A virus infection.

\section{Conclusion}

The FICT assay for the influenza $A$ virus was developed by combining the mAb conjugated with latex beads and coumarin-derived dendrimers for detection of the avian influenza virus and new human influenza virus (H1N1). The lowest detectable concentration (LDC) of the FICT assay was determined as $100 \mathrm{ng} / 10 \mu \mathrm{L}$, which was 2.5-fold higher than that of the dot blot immunoassay and colloidal gold-based rapid diagnostic strips. Moreover, the FICT assay could detect avian influenza virus subtypes (H5N3, H7N1, H7N7, and H9N2). On applying the clinical swab samples infected with respiratory viruses to FICT, all of the H1N1-positive patients were found to be positive and the enhanced LDC of the FICT assay allowed for diagnosis of $\mathrm{H} 1 \mathrm{~N} 1$ patients who were negative by RDT. Using the standard H1N1 virus antigen, the HAU titer of the influenza virus was quantified in all of the patients. In conclusion, a simple and quantitative diagnostic FICT assay was developed for enhanced detection of the influenza A virus, and therefore, this assay proposes to be an innovative diagnostic technology for application in clinical diagnosis.

\section{Acknowledgements}

This research was supported by the Public Welfare \& Safety Research Program through the National Research foundation of Korea (NRF) funded by the Ministry of Science, ICT \& Future Planning (2010-0020803). 


\section{Competing Interests}

The authors have declared that no competing interest exists.

\section{References}

1. Claas EC, Osterhaus AD, van Beek R, De Jong JC, Rimmelzwaan GF, Senne DA, Krauss S, Shortridge KF, Webster RG. Human influenza A H5N1 virus related to a highly pathogenic avian influenza virus. Lancet. 1998; 351: 472-477.

2. Hirst M, Astell CR, Griffith M, Coughlin SM, Moksa M, Zeng T, Smailus DE, Holt RA, Jones S, Marra MA, Petric M, Krajden M, Lawrence D, Mak A, Chow R, Skowronski DM, Tweed SA, Goh S, Brunham RC, Robinson J, Bowes V, Sojonky K, Byrne SK, Li Y, Kobasa D, Booth T, Paetzel M. Novel avian influenza H7N3 strain outbreak, British Columbia. Emerg Infect Dis. 2004; 10: 2192-2195.

3. Sandrock C, Kelly T. Clinical review: update of avian influenza A infections in humans. Crit Care. 2007; 11: 209.

4. Chowell G, Bertozzi SM, Colchero MA, Lopez-Gatell H, Alpuche-Aranda C, Hernandez M, Miller MA. Severe respiratory disease concurrent with the circulation of H1N1 influenza. N Engl J Med. 2009; 361: 674-679. doi:10.1056/NEJMoa0904023.

5. Kudo K, Binh NG, Manabe T, Co DX, Tuan ND, Izumi S, Takasaki J, Minh DH, Thuy PT, Van VT, Hanh TT, Chau NQ. Clinical preparedness for severe pneumonia with highly pathogenic avian influenza A (H5N1): experiences with cases in Vietnam. Respir Investig. 2012; 50: 140-150. doi: 10.1016/j.resinv.2012.08.005

6. Fouchier RA, Schneeberger PM, Rozendaal FW, Broekman JM, Kemink SA, Munster V, Kuiken T, Rimmelzwaan GF, Schutten M, Van Doornum GJ, Koch G, Bosman A, Koopmans M, Osterhaus AD. Avian influenza A virus (H7N7) associated with human conjunctivitis and a fatal case of acute respiratory distress syndrome. Proc Natl Acad Sci U S A. 2004; 101: 1356-1361.

7. Centers for Disease Control and Prevention (CDC). Notes from the field: Highly pathogenic avian influenza A (H7N3) virus infection in two poultry workers--Jalisco, Mexico, July 2012. MMWR Morb Mortal Wkly Rep. 2012; 61: 726-727.

8. Belser JA, Bridges CB, Katz JM, Tumpey TM. Past, present, and possible future human infection with influenza virus A subtype H7. Emerg Infect Dis. 2009; 15: 859-865. doi: 10.3201/eid1506.090072.

9. Gao R, Cao B, Hu Y, Feng Z, Wang D, Hu W, Chen J, Jie Z, Qiu H, Xu K, Xu X, Lu H, Zhu W, Gao Z, Xiang N, Shen Y, He Z, Gu Y, Zhang Z, Yang Y, Zhao X, Zhou L, Li X, Zou S, Zhang Y, Li X, Yang L, Guo J, Dong J, Li Q, Dong L, Zhu Y, Bai T, Wang S, Hao P, Yang W, Zhang Y, Han J, Yu H, Li D, Gao GF, Wu G, Wang Y, Yuan Z, Shu Y. Human infection with a novel avian-origin influenza A (H7N9) virus. N Engl J Med. 2013; 368: 1888-1897. doi: 10.1056/NEJMoa1304459.

10. Butt KM, Smith GJ, Chen H, Zhang LJ, Leung YH, Xu KM, Lim W, Webster RG, Yuen KY, Peiris JS, Guan Y. Human infection with an avian H9N2 influenza A virus in Hong Kong in 2003. J Clin Microbiol. 2005; 43: 5760-5767.

11. Pascua PN, Choi YK. Zoonotic infections with avian influenza A viruses and vaccine preparedness: a game of "mix and match". Clin Exp Vaccine Res. 2014; 3: 140-148. doi: 10.7774/cevr.2014.3.2.140.

12. Lien KY, Hung LY, Huang TB, Tsai YC, Lei HY, Lee GB. Rapid detection of influenza A virus infection utilizing an immunomagnetic bead-based microfluidic system. Biosens Bioelectron 2011; [Epub ahead of print]

13. Steininger C, Kundi M, Aberle SW, Aberle JH, Popow-Kraupp T. Effectiveness of reverse transcription-PCR, virus isolation, and enzyme-linked immunosorbent assay for diagnosis of influenza A virus infection in different age groups. J Clin Microbiol. 2002; 40: 2051-2056.

14. Vinikoor M, Stevens J, Nawrocki J, Singh K. Influenza A virus subtyping: paradigm shift in influenza diagnosis. J Clin Microbiol. 2009; 47: 3055-3056. doi: 10.1128/JCM.01388-09.

15. Bai GR, Sakoda Y, Mweene AS, Fujii N, Minakawa H, Kida H. Improvement of a rapid diagnosis kit to detect either influenza A or B virus infections. J Vet Med Sci. 2006; 68: 35-40.

16. Drexler JF, Helmer A, Kirberg H, Reber U, Panning M, Müller M, Höfling K, Matz B, Drosten C, Eis-Hübinger AM. Poor clinical sensitivity of rapid antigen test for influenza A pandemic (H1N1) 2009 virus. Emerg Infect Dis. 2009; 15: 1662-1664. doi: 10.3201/eid1510.091186.

17. Kim WS, Lee GC, Yoo JH, Kim HY, Yun YP, Chong CK. Development and diagnostic application/evaluation of pandemic (H1N1) 2009 influenza virus-specific monoclonal antibodies. Microbiol Immunol. 2012; 56: 372-377. doi: 10.1111/j.1348-0421.2012.00455.x.

18. Lee CK, Cho CH, Woo MK, Nyeck AE, Lim CS, Kim WJ. Evaluation of Sofia fluorescent immunoassay analyzer for influenza A/B virus. J Clin Virol. 2012; 55: 239-243. doi: 10.1016/j.jcv.2012.07.008.

19. Shekalaghe S, Cancino M, Mavere C, Juma O, Mohammed A, Abdulla S, Ferro $\mathrm{S}$. Clinical performance of an automated reader in interpreting malaria rapid diagnostic tests in Tanzania. Malar J. 2013; 12: 141 . doi: 10.1186/1475-2875-12-141.
20. He L, Ozdemir SK, Zhu J, Kim W, Yang L. Detecting single viruses and nanoparticles using whispering gallery microlasers. Nat Nanotechnol. 2011; 6: 428-432. doi: 10.1038/nnano.2011.99.

21. Chou TC, Hsu W, Wang CH, Chen YJ, Fang JM. Rapid and specific influenza virus detection by functionalized magnetic nanoparticles and mass spectrometry. J Nanobiotechnology. 2011; 9: 52. doi: 10.1186/1477-3155-9-52.

22. Li Y, Hong M, Oiu B, Lin Z, Chen Y, Cai Z, Chen G. Highly sensitive fluorescent immunosensor for detection of influenza virus based on Ag autocatalysis. Biosens Bioelectron. 2014; 54: 358-364. doi: 10.1016/j.bios.2013.10.045.

23. Zhou CH, Zhao JY, Pang DW, Zhang ZL. Enzyme-induced metallization as a signal amplification strategy for highly sensitive colorimetric detection of avian influenza virus particles. Anal Chem. 2014; 86: 2752-2759. doi: $10.1021 /$ ac404177c.

24. Deregt D, Furukawa-Stoffer TL, Tokaryk KL, Pasick J, Hughes KM, Hooper-McGrevy K, Baxi S, Baxi MK. A microsphere immunoassay for detection of antibodies to avian influenza virus. J Virol Methods. 2006; 137: 88-94.

25. Zhang J, Tian J, He Y, Chen S, Jiang Y, Zhao Y, Zhao S. Protein-binding aptamer assisted signal amplification for the detection of influenza A (H1N1) DNA sequences based on quantum dot fluorescence polarization analysis. Analyst. 2013; 138: 4722-4727. doi: 10.1039/c3an00830d.

26. Yeo SJ, Huong DT, Han JH, Kim JY, Lee WI, Shin HJ, Han ET, Park H. Performance of coumarin-derived dendrimer-based fluorescence-linked immunosorbent assay (FLISA) to detect malaria antigen. Malar J. 2014; 13: 266. doi: 10.1186/1475-2875-13-266.

27. Shaw ML, Stone KL, Colangelo CM, Gulcicek EE, Palese P. Cellular proteins in influenza virus particles. PLoS Pathog. 2008; 4: e1000085. doi: 10.1371/ journal.ppat. 1000085 .

28. Song HO, Lee B, Bhusal RP, Park B, Yu K, Chong CK, Cho P, Kim SY, Kim HS, Park $H$. Development of a novel fluorophore for real-time biomonitoring system. PLoS One. 2012; 7:e48459. doi: 10.1371/journal.pone.0048459.

29. Shin HS, Kim CK, Shin KS, Chung HK, Heo TR. Pretreatment of whole blood for use in immunochromatographic assays for hepatitis B virus surface antigen. Clin Diagn Lab Immunol. 2001; 8: 9-13.

30. Li X, Li W, Yang O, Gong X, Guo W, Dong C, Liu J, Xuan L, Chang J. Rapid and quantitative detection of prostate specific antigen with a quantum dot nanobeads-based immunochromatography test strip. ACS Appl Mater Interfaces. 2014; 6: 6406-6414. doi: 10.1021/am5012782.

31. Khreich N, Lamourette P, Lagoutte B, Ronco C, Franck X, Créminon C, Volland $\mathrm{H}$. A fluorescent immunochromatographic test using immunoliposomes for detecting microcystins and nodularins. Anal Bioanal Chem. 2010; 397: 1733-1742. doi: 10.1007/s00216-009-3348-x.

32. Karakus C, Salih BA. Comparison of the lateral flow immunoassays (LFIA) for the diagnosis of Helicobacter pylori infection. J Immunol Methods. 2013; 396: 8-14. doi: 10.1016/j.jim.2013.08.010.

33. Tsunetsugu-Yokota Y, Nishimura K, Misawa S, Kobayashi-Ishihara M, Takahashi H, Takayama I, Ohnishi K, Itamura S, Nguyen HL, Le MT, Dang GT, Nguyen LT, Tashiro M, Kageyama T. Development of a sensitive novel diagnostic kit for the highly pathogenic avian influenza A (H5N1) virus. BMC Infect Dis. 2014; 14: 362. doi: 10.1186/1471-2334-14-362

34. Chen L, Sheng Z, Zhang A, Guo X, Li J, Han H, Jin M. Quantum-dots-based fluoroimmunoassay for the rapid and sensitive detection of avian influenza virus subtype H5N1. Luminescence. 2010; 25: 419-423. doi: 10.1002/bio.1167

35. Cho CH, Woo MK, Kim JY, Cheong S, Lee CK, An SA, Lim CS, Kim WJ. Evaluation of five rapid diagnostic kits for influenza A/B virus. J Virol Methods. 2013; 187: 51-56. doi: 10.1016/j.jviromet.2012.09.003. 